\title{
Stress Management Amidst of the Covid-19 Pandemic of Public Junior High School Teachers in Selected High School of Aborlan North District
}

\author{
Eliza A. Panis 8 (D) \\ Principal II, Marcelo A. Bantug National High School, Aborlan North District, Division of Palawan, Department of Education, \\ Aborlan, Palawan, Philippines
}

$\triangle$ Corresponding Author: Eliza A. Panis, E-mail: eliza.panis0001@deped.gov.ph.com

ARTICLE INFORMATION ABSTRACT

Received: April 08, 2021

Accepted: May 14, 2021

Volume: 3

Issue: 5

DOI: $10.32996 /$ jweep.2021.3.5.4

\section{KEYWORDS}

Covid-19 pandemic, teachers, stress management, years of service, sources of stress, workrelated stress, level of perceived stress, job-related
This study was conducted from February 2021 to March 2021 to determine the stress management amidst the covid - 19 pandemics of the junior high school teachers in selected high schools of Aborlan North. The descriptive research design, specifically the survey method, was used in this study. Data were gathered through survey questionnaires. A total of 39 permanent teachers were enumerated from the selected high schools as the respondents of the study. The result showed that most of the respondents were married females in their middle age. They had been in the service for a mean of 11.3 years and almost three fourth $(74.4 \%)$ of them were Secondary School Teacher I with a mean teaching load of 26.4 hours per week. The perceived sources of stress such as work, family, personal, and environmental were considered distinctly part of the respondents' lives. The level of perceived stress of the respondents was noted to be "high stress". The activities engaged in very often to manage stress by a majority of the respondents were walking, praying, attending church/religious service, planting, gardening, and watering plants, washing domes, cooking/baking, evaluating oneself, watching the news, watching entertainment programs, watching "teledramas", "telenovelas", listening to music, texting, going to the internet, and talking with a family member.

\section{Introduction}

Stress can be defined as any type of change that causes physical, emotional, or psychological strain. However, not all types of stress are harmful or even negative. There are a few different types of stress that a person encounters: eustress, a type of stress that is fun and exciting, and keeps one vital (e.g. racing to meet a deadline), acute stress, a very short-term type of stress that can either be positive (eustress) or more distressing (or what is normally thought of when as 'stress'); this is the type of stress one most often encounters in day-to-day life episodic acute stress, where acute stress seems to run rampant and be a way of life, creating a life of relative chaos; chronic stress, the type of stress that seems never-ending and inescapable, like the stress of a bad marriage or an extremely taxing job (this type of stress can lead to burnout) (U.S. National Library of Medicine, 2020).

Stress will always be a part of human life. Whether individually or corporate, at work or play, one is pressured to make decisions, take actions or even change one's behaviors. It makes ones' life meaningful depending on the way it is being handled.

Stress is a normal part of life. At times, it serves a useful purpose. Stress can motivate you to get that promotion at work or run the last mile of a marathon. But if you do not get a handle on your stress and it becomes long-term, it can seriously interfere with your job, family life, and health (WebMD, 2019).

Stress management involves controlling and reducing the tension that occurs in stressful situations by making emotional and physical changes. The degree of stress and the desire to make the changes will determine how much change takes place. A

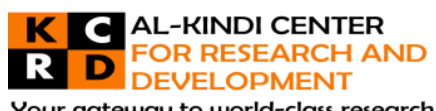

Your gateway to world-class research

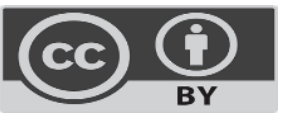

Published by Al-Kindi Center for Research and Development. Copyright (c) the author(s). This open access article is distributed under a Creative Commons Attribution (CC-BY) 4.0 license 
person's attitude can influence whether or not a situation or emotion is stressful. A person with a negative attitude will often report more stress than would someone with a positive attitude (U.S. National Library of Medicine, 2020).

Subsequent studies of stress in humans by WikiDoc (2021) and others established the view that distinct, measurable life stressors cause stress, and further, that these life stressors can be ranked by the median degree of stress they produce (leading to the Holmes and Rahe Stress Scale). Thus, stress was traditionally conceptualized to be a result of external insults beyond the control of those experiencing the stress. More recently, however, it has been argued that external circumstances do not have any intrinsic capacity to produce stress, but instead, their effect is mediated by the individual's perceptions, capacities, and understanding.

Job stress can be defined as the harmful physical and emotional responses that occur when the job requirements do not match the capabilities, resources, or needs of the worker. Job stress can lead to poor health and even injury. According to one school of thought, differences in individual characteristics such as personality and coping style are most important in predicting whether certain job conditions will result in stress. In other words, what is stressful for one person may not be a problem for someone else (www.cdc.gov/niosh/pdfs/stress.pdf).

Some employers assume that stressful working conditions are a necessary evil that companies must turn up the pressure on workers and set aside health concerns to remain productive and profitable in today's economy. However, research findings challenge this belief. Studies show that stressful working conditions are associated with increased absenteeism, tardiness, and intentions by workers to quit their jobs, all of which harm the bottom line. Recent studies of so-called healthy organizations suggest that policies benefiting worker's health also benefit the bottom line (www.cdc.gov/niosh/pdfs/stress.pdf).

Stress is a popular topic and everybody faces stress in his life since it is a normal part of life and inevitable but not necessarily a completely bad part. Learning the ability on how to handle it would be a challenging part of a person's life.

\section{Literature Review}

\subsection{On Stress and Stress Level}

According to WebMD, 2019, stress is a normal part of life. At times, it serves a valuable purpose. Stress can motivate you to get that promotion at work or run the last mile of a marathon. But if you do not get a handle on your stress and it becomes longterm, it can seriously interfere with your job, family life, and health.

Stress is subjective. Some symptoms that may indicate stress are headaches, muscle spasms, teeth grinding, aching jaw, indigestion, nausea, ulcers, diarrhoea, constipation, shortness of breath, heart palpitations, cold hands and feet, and various skin problems including acne, eczema, and psoriasis. The common effect of stress on behavior may be easily discernible. Some common features include pacing and fidgeting, talking too fast and rushing everywhere, hyperventilation, nervous tics such are wringing hands, inability to relax, crying, constant fatigue, increased fatigue, substance abuse, indecisiveness, insomnia, and sleeping problems, increased eating and weight gain, loss of effectiveness at work, overspending, increased smoking and drinking (http://www.janicehealth.com/stress.htm , 2008).

Emotional stress usually occurs when people consider situations difficult or unable to manage. Different people consider different situations as stressful. On the other hand, physical stress refers to the body's physical reaction to various triggers. The pain experienced after surgery is an example of physical stress. Physical stress often leads to emotional stress, and emotional stress often occurs as physical discomfort (e.g., stomach cramps) (U.S. National Library of Medicine, 2020).

Unfortunately, many people find that when they are under stress, their sex drive suffers. In fact, a recent study showed that more than half the partners of people working over 48 hours a week reported that it was damaging their sex life. Fortunately, the same factors that can decrease the level of stress one feels can rev up his libido at the same time (Pera, G., 2021).

Meditation is wonderful in that it is free, is always available, and is amazingly effective in short-term stress reduction and longterm health. Benefits can be felt in just one session (Scott, E., 2020).

According to UCSB Science Line (2021), stress is a major factor in diseases with a significant psychosomatic component, that is, diseases whose physical symptoms are induced or aggravated by mental or emotional disturbances. Stress-related disorders compose 50 to 80 percent of all illnesses, though stress may not be the only cause. 
When the body is unable to cool itself by sweating, several heat-induced illnesses such as heat stress or heat factors leading to heat stress high temperature and humidity; direct sun or heat; limited air movement; physical exertion; poor physical condition; some medicines; and inadequate tolerance for hot workplaces (www.osha.gov/Publications/osha3154.pdf).

\subsection{On Sources of Stress}

There are so many things at work that can play instrumental roles in causing stress. The following rank among some of the major causes of stress at work: Stress resulting from overworking yourself or being overworked. Stress in the workplace can come from being overworked. This is one of the most common causes of stress at the workplace. Co-workers can be a source of stress.

Stress at a workplace can also come about as a result of a person's co-workers. Some co-workers excuse me for saying they can sometimes be 'monsters'. Some people are known to bully their co-workers, use degrading words on them or even try their best to sabotage the work of others. There also other cases of workers harassing their co-workers sexually. You can also get stressed if you find yourself in the wrong job. Someone once said that the worst thing that could happen to a person is to wake up every morning and go to the very job that you hate or cannot do very well. If you hate a particular job, then it goes without saying that doing it is going to be a stressful experience for you. Also, if you find yourself in a job in which you do not have sufficient skills to handle, you will find it extremely difficult to do it, and of course, that will give you a lot of stress. Another major cause of stress at work is as a result of the work environment. According to experts, the environment in which you work can also play a major role in causing stress. Lack of a proper support network at work can also contribute to stress at work (HOSBEG, 2020).

Stress may be caused by work pressures, travel, home environment, mental trauma, anxiety, depression, poor food habits, family problems, marriage-related issues, the physical environment, and in many cases by factors out of one's physical control (http://www.janicehealth.com/stress.htm, 2008).

Sleep deprivation is one of the leading causes of stress. And stress is one of the leading causes of insomnia. It is important to maintain a regular sleep routine, avoiding large meals just before sleeping, and getting regular exercise. It is also important to avoid exercise just before sleep time and extremely important to buy a comfortable bed and pillows. Ensure you have the right blankets and comfortable room temperature, making you fall asleep naturally (http://www.janicehealth.com/stress.htm , 2008).

According to Feldren (2005), personal stressors include major life events such as the death of a parent or spouse, the loss of one's job, a major personal failure, or even something positive such as getting married. However, background stressors, or more informally, daily hassles, are the third major category of stressors exemplified by standing in a long line at a bank and getting stuck in a traffic jam. Daily hassles are the minor irritations of life that everybody faces time and time again: delays, noisy cars and trucks, broken appliances, other people's irritating behavior, and so on.

DeLongis et al., as cited by Morgan (1986), said that not only changes but many ongoing situations are stressors. These include physical stressors such as injury, infection, exercise, noise, and climate. In addition, the hassles of everyday life centering around work, family, social activities, health, and finances are important stressors that are related to bodily illness.

\subsection{On Coping with Stress}

On a positive note, research indicates that spending time in nature and including more nature in your life - even houseplants or nature artwork in your home and office - can reduce your stress.

Putting nature back into your life what urban or even rural expansion has taken away can directly counter this stress. Create spaces and times where and when you can enjoy complete quietude, reclaiming your power over the noisy world. If you cannot move away from a noisy highway or railroad, get white noise generators or small fountains that play the sounds of nature while you rest (Group, D. E. 2018).

Here are some ways to reduce the impact of the many environmental stressors we all face. Reduce exposure to the stressor. It might go without saying, but the most important and easiest way to reduce environmental stress involves minimizing your exposure. This is not always possible, but in many cases, it is unfortunately, not everyone can easily move away from certain environmental stressors. This is especially true for individuals who often do not have the resources to move away from harmful environments. If you can move or get away from a stressor, do so. If you have to stay, your solutions will depend on the particular stressor you face. If you live near a noisy highway or railroad, you can use noise-canceling white noise generators in your home or play nature sounds while you sleep. If the issue is a chemical plant, you can use a good quality air filter to reduce pollutants and change them regularly, have excellent insulation in your home, and plant trees and shrubs in your yard to help absorb chemicals and noise (InterFocus, 2019). 
It might sound overly simplistic, but just taking a moment to breathe deeply and collect your thoughts can help you handle stress more effectively. When you can feel the stress beginning to build, try breathing in deeply through your nose, holding the breath for a few moments, and then exhaling slowly through the mouth. Continue to do this a few times and you will start to feel a little calmer. Learn to Say 'No'. This is difficult to get used to in a highly competitive environment, but learning to say 'no' is an important skill for minimizing stress. Many of us think we must say 'yes' to any additional work for fear of missing out or looking bad, but this can lead to us becoming overloaded. Learn to say 'no' when people ask for help or additional tasks completing if you genuinely do not have time (InterFocus, 2019).

An individual stress management program can include making an effort to stop negative thoughts, planning some fun, focusing the negative into the positive, taking a break, and thinking positively (U.S. National Library of Medicine, 2020).

Research has shown the health benefits of laughter, ranging from strengthening the immune system to reducing food cravings to increasing one's threshold for pain. There is even an emerging therapeutic field known as humor therapy to help people heal more quickly, among other things. Humor also has several important stress-relieving benefits (http://www.janicehealth.com/stress.htm , 2008).

One may be able to reduce stress by changing his diet. Foods and beverages that are helpful can be found in many stores. Herbal teas such as chamomile and peppermint have a calming effect. Food high in vitamin B-6 like yeast extracts, liver, whole grains, nuts, and bananas are categorized as stress preventers. Citrus fruits, bell peppers, and baked potatoes are rich in vitamin C, which help the human body to maintain resistance to infection when under stress (http://www.janicehealth.com/stress.htm , 2008).

Changing one's perspective can help cope with stress. Sometimes you find yourself in a stressful situation at work that you have no control over, but changing the way you think about the problem can help you cope with it better. Try to focus on the things in life that are important, rather than letting work stresses take over. Focus on spending time with your family and friends, planning some fun activities away from the office (InterFocus, 2019).

The philosophy of positivism can fight stress. By changing the way, one thinks, one can turn a negative experience into a positive one. This new look at life can help fight stress and reduce its occurrence (http://www.janicehealth.com/stress.htm , 2008).

The American Psychological Association mentioned the following on how stress coping skills be improved. Talk about it, if you notice that your children are looking worried or stressed, ask them what's on their minds. Having regular conversations can help a family work together to better understand and address any stressors children are experiencing. Low levels of parental communication have been associated with poor decision-making among children and teens. Talking to your children and promoting open communication and problem-solving is just as important as eating well and getting enough exercise and sleep. Create a healthy environment. Your home, workspace, and even social environment can influence your behaviors (American Psychological Association, 2019).

Exercise can decrease 'stress hormones' like cortisol, and increase endorphins, the body's 'feel-good' chemicals, giving one's mood a natural boost. It usually involves a change of scenery as well, either taking a person to a gym, a dojo, a boxing ring, a park, a scenic mountain, a biking trail, or a neighborhood sidewalk, all of which can be pleasant, low-stress places (Star, K., 2019).

Research has shown that music profoundly affects the body and psyche. There is a growing field of health care known as "Music Therapy", which uses music to heal. Those who practice music therapy are finding a benefit in using music to help cancer patients, children with $A D D$, and others, and even hospitals are beginning to use music and music therapy to help with pain management, to help ward off depression, to promote movement, to calm patients, to ease muscle tension, and for many other benefits that music and music therapy can bring. Music can also be used to bring a more positive state of mind, helping to keep depression and anxiety at bay. This can help prevent the stress response from wreaking havoc on the body and can help keep creativity and optimism levels higher, bringing many other benefits (Arora, C. S., 2011).

Deep breathing is an easy stress reliever that has numerous benefits for the body, including oxygenating the blood, which 'wakes up' the brain, relaxing muscles, and quieting the mind. Breathing exercises are especially helpful because you can do them anywhere, and they work quickly so you can de-stress in a flash (Vilibrium, 2021).

The physical benefits of sex are numerous, and most of them work very well toward relieving stress. Sadly, many people have less sex when their stress levels are high (HAMMY, 2021). 
Music therapy has shown numerous health benefits for people with conditions ranging from mild (like stress) to severe (like cancer). When dealing with stress, the right music can lower your blood pressure, relax your body and calm your mind (Scott, E., 2020).

Lazarus and Folkman's interpretation of stress focuses on the transaction between people and their external environment (known as the Transactional Model). The model conceptualizes stress as a result of how a stressor is appraised and how a person appraises his/her resources to cope with the stressor. The model breaks the stressor-stress link by proposing that if stressors are perceived as positive or challenging rather than a threat, and if the stressed person is confident that he/she possesses adequate rather than deficient coping strategies, stress may not necessarily follow the presence of a potential stressor. The health realization/innate health model of stress is also founded on the idea that stress does not necessarily follow the presence of a potential stressor. Instead of focusing on the individual's appraisal of so-called stressors about his or her coping skills (as the transactional model does), the health realization model focuses on the nature of thought, stating that it is ultimately a person's thought processes that determine the response to potentially stressful external circumstances (Wikipedia, the free encyclopedia, 2020).

Moreover, as cited by Feldren (2005), Moskowitz enumerated some general guidelines that can be followed in coping with stress. These guidelines are as follows: turn a threat into a challenge, make a threatening situation less threatening, change one's goals, take physical action, and prepare for stress before it happens.

Stress experts frequently emphasize that stress can be good as well as bad and advise their patients to make it work for them as a source of energy. They suggest the following ways to manage stress: (1) Have a code of life and live positively. (2) Set priorities to avoid unnecessary time pressures. (3) Allow time for pleasurable activities such as taking walks or talking with friends. (4) Exercise regularly as an outlet for stress. (5) Eat a sensible diet to maintain the energy needed to cope with stress. (6) Learn selfrelaxation techniques such as deep breathing, muscle relaxation, and meditation (UCSB Science Line, 2021).

Stress can be reduced by making lifestyle changes, keep a positive attitude, accept that stress is a part of life, clearly define home and work responsibilities, manage time, set realistic goals, learn to relax, eat an adequate and nutritious breakfast each day (Ohio State University Extension, 2020).

\subsection{On Demographic Characteristic}

It seems to be common knowledge that women are generally busier and more stressed than men, that they juggle more roles and are constantly rushing. Research from The University of Arizona's School of Family and Consumer Resources decided to find out. The results indeed showed that women reported a greater amount of "high distress" days and fewer distress-free days than men. Interestingly, the differences in levels of stressful days were due to women experiencing more onsets of "distress episodes" (having stress response triggered), rather than being more likely to continue in a distressed state from one day to the next. In other words, women did not hold onto their stress more; they just experienced more episodes of being stressed (Scott, E., 2020).

On the other hand, (http://www.lifeposhive.com/mind/psychology/stress/depressionaspect) as cited by Dancil (2008) stated that causes of female and male depression and anxiety might be quite different from each other. It is not known for sure if stress affects men and women differently. Generally, as the two genders often operate in different social contexts both tend to develop different emotional dispositions and personality traits accordingly; their responses and coping mechanisms to stress situations vary.

A study by Gamoso (2008) aimed to determine the stress management of Western Philippines University faculty members. Findings indicated that age, number of years in teaching, highest educational attainment, teaching load had a significant relationship with the level of perceived stress which implies that the higher the rank and educational attainment, the longer the length of service and the older the faculty member, regardless of age, the lower is the perceived stress, however, the more teaching load is assigned to the faculty member the higher is the level of perceived stress.

\subsection{Conceptual Framework}

This study has three variables: the independent, intervening, and dependent variables. The independent variables include demographic characteristics, job-related factors, and other factors. The intervening variables include sources of stress and activities for managing stress. Meanwhile, the dependent variable includes the level of stress. The level of stress of the public secondary school teachers will be categorized as high stress, moderate stress, and low stress. 


\section{Methodology}

\subsection{Research Design}

The research design used in this study is the descriptive research method, specifically the survey method. According to Gay and Sean, as cited by Santiago (2005), the descriptive method is useful for investigating educational problems especially those concerning the assessment of attitudes, opinions, preferences, practices, and procedures. This design is used to determine the perceived level of stress, the sources of stress, and the activities for reducing stress among the respondents.

\subsection{Respondents of the Study}

The respondents of the study were the public junior high school teachers in selected secondary schools in Aborlan North district Palawan. Teachers from the selected schools were enumerated as respondents of the study. Thirty-nine (39) junior school teachers were the respondents of the study.

\section{Results and Discussion}

\subsection{Demographic Characteristics of the Respondents}

Table 1. Distribution of the respondents as to their demographic characteristics.

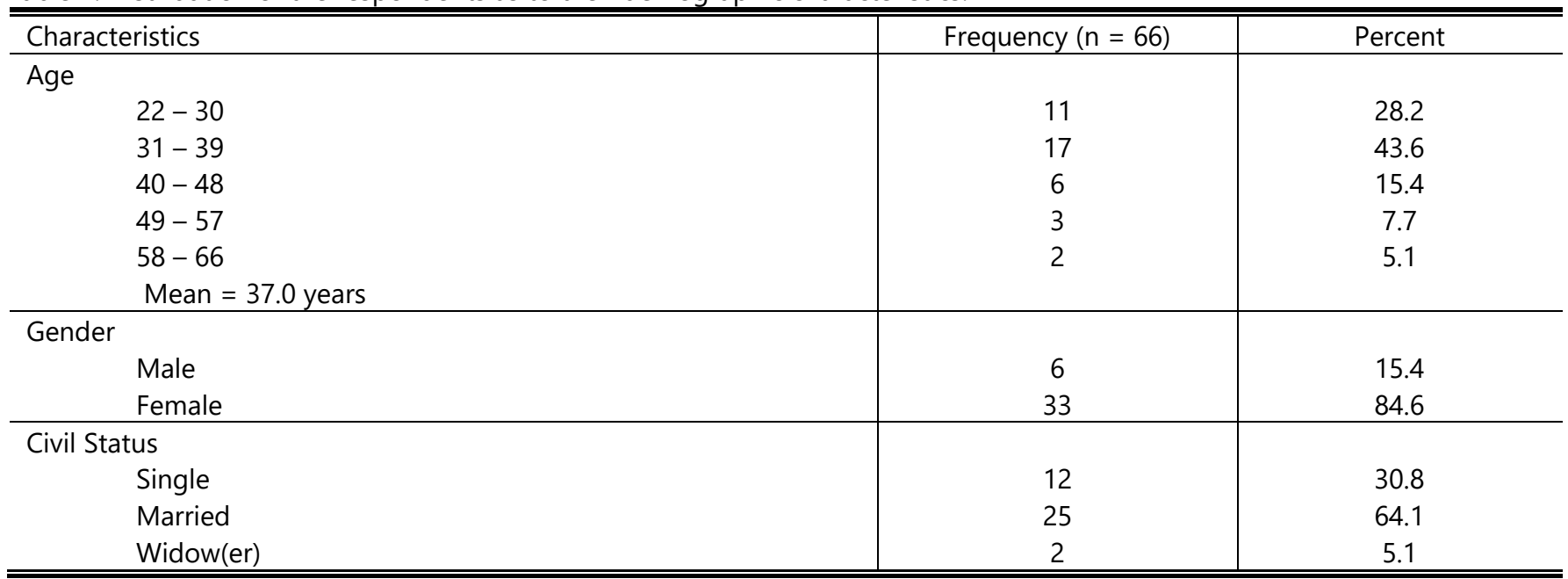

Results revealed that 84.6 percent are females and 15.4 percent of the respondents are males. This result implies that females lead public junior high school teachers of Aborlan North.

Most of the respondents (43.6\%) were in the age range of 31 to 39 years old, eleven (28.2 \%) were between 22 to 39 , and six (15.4\%) respondents were 40 to 48 years old. Three (7.7\%) respondents belonged to the age bracket of 49 to 57 years old and only two (5.1\%) were in the age range of 60 to 66 . Their mean age was 37 years old.

As to their civil status, a majority (64.1\%) were married, twelve (30.8\%) of them were single, two (5.1\%) were widows(er).

\subsection{Job-related Characteristics of the Respondents}

Table 2. Distribution of the respondents as to their job-related characteristics.

\begin{tabular}{c|c|c}
\hline \multicolumn{1}{c|}{ Characteristics } & Frequency $(\mathrm{n}=39)$ & Percent \\
\hline \hline Number of Years in Teaching & & 48.7 \\
$1-8$ & 12 & 30.8 \\
$9-16$ & 3 & 7.7 \\
$17-24$ & 2 & 5.1 \\
$25-32$ & 3 & 7.7 \\
$33-40$ & & \\
Mean $=11.3$ years & & \\
\hline
\end{tabular}




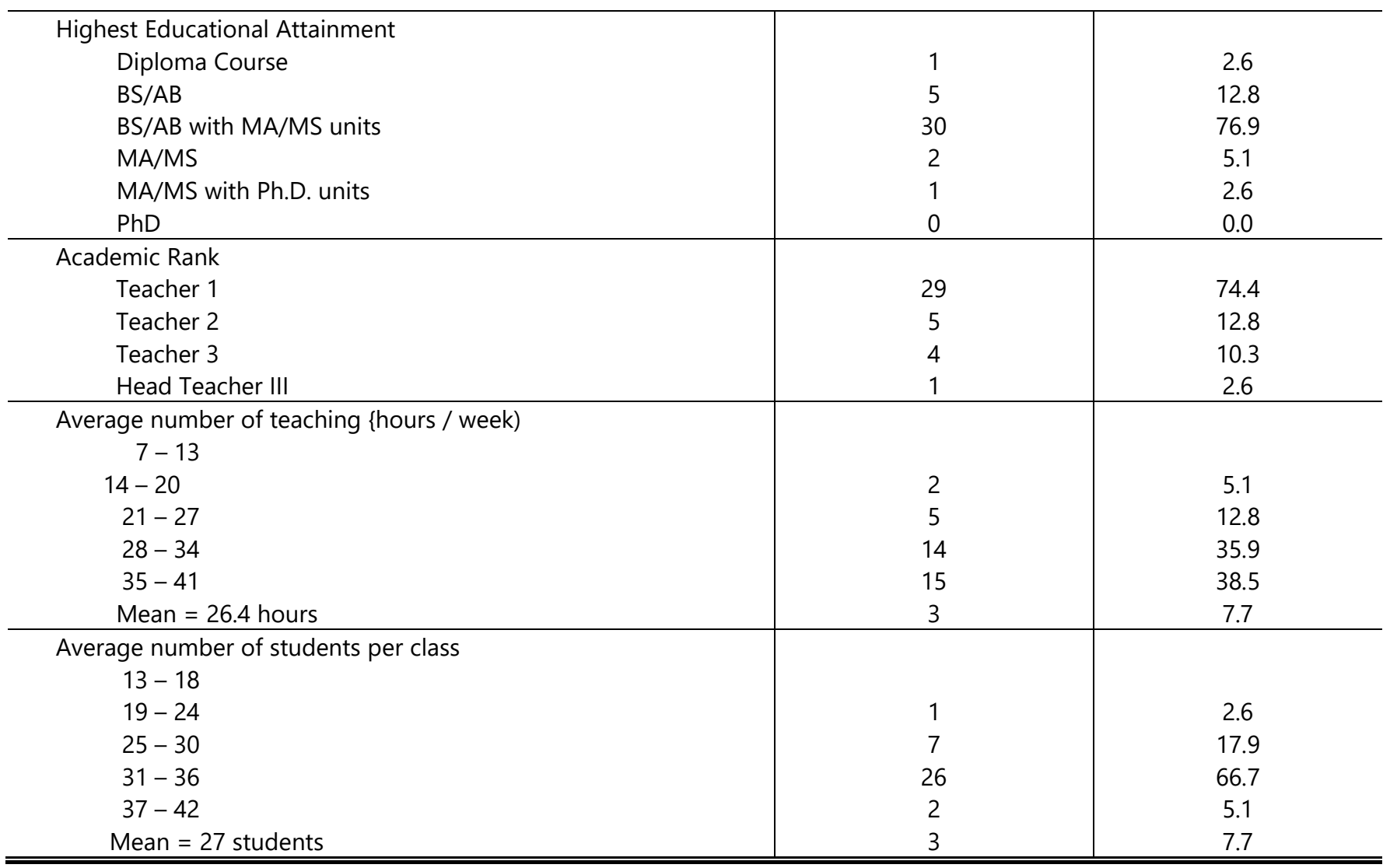

Data revealed that the majority (48.7\%) of the respondents had been in the service for 1 to 8 years, twelve $(27.3 \%)$ of the respondents had been in the service for 9 to 16 years; three (7.7\%) for 17 to 24 and 33 to 40 years old (7.7\%) and only two (5.1\%) of them had been in the service for 25 to 32 years. Their average number of years in teaching was 11.3 years. It implies that the respondents have been teaching for quite a long time now.

As to academic rank, twenty-nine (74.4\%) of the respondents are Secondary School Teachers I, five (12.8\%) are Secondary School Teachers II and some (10.3\%) are Secondary School Teachers III. Only one (2.6\%) is Head Teacher III. This result implies that most of the respondents hold a lower academic rank.

The table also shows that 38.5 percent of the respondents had a teaching load of 21 to 27 hours per week. Fourteen (35.9\%) had a teaching load of 21 to 27 hours per week. Few (12.8\%) had a teaching load of 14 to 20 hours per week, three (7.7\%) had a teaching load of 35 to 41 hours per week and two (5.1\%) had a teaching load of 7 to 13 hours per week. Their average teaching load per week is 26.4 hours. This implies that the respondents have complied with the minimum prescribed number of hours in teaching which is 18 hours per week.

The data further reveals that 26 (66.7\%) had 25 to 30 average number of students per class, seven (17.9\%) had 19 to 24 average number of students per class, three (7.7\%) had 37 to 42 average number of students per class, two (5.5\%) had 31 to 36 average number of students per class and only one (2.6\%) had 13 to 18 average number of students per class. This means that most of the respondents have complied with the minimum prescribed number of students per class which is 25 to 40 .

\subsection{Work-related Sources of Stress as Perceived by the Respondents}

Table 3. Work-related sources of stress as perceived by the respondents.

\begin{tabular}{c|c|c|c|c|c|c|c|c|c|c}
\hline \hline \multirow{2}{*}{$\begin{array}{c}\text { Work-Related Sources of } \\
\text { Stress }\end{array}$} & \multicolumn{2}{|c|}{$\begin{array}{c}\text { Very Much } \\
\text { Part }\end{array}$} & \multicolumn{2}{|c|}{ Distinctly Part } & \multicolumn{2}{c|}{$\begin{array}{c}\text { Only Slightly } \\
\text { Part }\end{array}$} & \multicolumn{2}{|c|}{$\begin{array}{c}\text { Not at All } \\
\text { Part }\end{array}$} & $\begin{array}{c}\text { Mean } \\
\text { Score }\end{array}$ & Description \\
\cline { 2 - 10 } & $\mathrm{f}$ & $\%$ & $\mathrm{f}$ & $\%$ & $\mathrm{f}$ & $\%$ & $\mathrm{f}$ & $\%$ & & \\
\hline $\begin{array}{c}\text { Dissatisfaction with the } \\
\text { distribution and retrieval of } \\
\text { students' modules }\end{array}$ & 4 & 10.8 & 16 & 43.2 & 17 & 45.9 & 0 & 0 & 3.49 & Very much part \\
\hline
\end{tabular}




\begin{tabular}{|c|c|c|c|c|c|c|c|c|c|c|}
\hline $\begin{array}{l}\text { Heavy demands for printing } \\
\text { and sorting of students' } \\
\text { modules }\end{array}$ & 10 & 26.3 & 21 & 55.3 & 7 & 18.4 & 0 & 0 & 3.08 & Very much part \\
\hline $\begin{array}{l}\text { A lot of examinations/ } \\
\text { students' modules or paper } \\
\text { works to check }\end{array}$ & 11 & 28.2 & 20 & 51.3 & 8 & 20.5 & 0 & 0 & 3.08 & Very much part \\
\hline $\begin{array}{l}\text { Dissatisfaction with the } \\
\text { attitudes of the students } \\
\text { towards answering the } \\
\text { modules }\end{array}$ & 11 & 28.2 & 15 & 38.5 & 12 & 30.8 & 1 & 2.6 & 2.92 & Very much part \\
\hline $\begin{array}{l}\text { Shortage of school supplies for } \\
\text { the printing of students' } \\
\text { modules }\end{array}$ & 4 & 10.3 & 24 & 61.5 & 11 & 28.2 & 0 & 0 & 2.82 & Very much part \\
\hline A lot of work responsibilities & 8 & 20.5 & 15 & 38.5 & 15 & 38.5 & 1 & 2.6 & 2.77 & Very much part \\
\hline $\begin{array}{c}\text { Preparing and editing } \\
\text { students' modules }\end{array}$ & 5 & 12.8 & 18 & 46.2 & 13 & 33.3 & 3 & 7.7 & 2.64 & Very much part \\
\hline $\begin{array}{l}\text { Dissatisfaction with the } \\
\text { learning styles/abilities of } \\
\text { the students }\end{array}$ & 4 & 10.3 & 15 & 38.5 & 20 & 51.3 & 0 & 0 & 2.59 & Very much part \\
\hline Preparing rushed documents & 2 & 5.1 & 19 & 48.7 & 16 & 41 & 2 & 5.1 & 2.54 & Very much part \\
\hline Meeting deadlines & 3 & 7.7 & 16 & 41 & 19 & 48.7 & 1 & 2.6 & 2.54 & Very much part \\
\hline $\begin{array}{l}\text { Preparing for the school } \\
\text { evaluation/school visitation }\end{array}$ & 3 & 7.9 & 16 & 42.1 & 16 & 42.1 & 3 & 7.9 & 2.5 & Very much part \\
\hline Preparing Work Weekly plan & 3 & 7.7 & 16 & 41 & 17 & 43.6 & 3 & 7.7 & 2.49 & Distinctly Part \\
\hline $\begin{array}{l}\text { Preparing instructional } \\
\text { materials }\end{array}$ & 4 & 10.3 & 13 & 33.3 & 19 & 48.7 & 3 & 7.7 & 2.46 & Distinctly Part \\
\hline $\begin{array}{l}\text { Rendering service beyond the } \\
\text { official time }\end{array}$ & 6 & 15.4 & 9 & 23.1 & 20 & 51.3 & 4 & 10.3 & 2.44 & Distinctly Part \\
\hline $\begin{array}{l}\text { Dissatisfaction with the } \\
\text { teaching materials provided } \\
\text { by the school }\end{array}$ & 1 & 2.6 & 15 & 38.5 & 22 & 56.4 & 1 & 2.6 & 2.41 & Distinctly Part \\
\hline $\begin{array}{l}\text { Heavy demands from the } \\
\text { supervisor }\end{array}$ & 1 & 2.6 & 11 & 28.2 & 25 & 64.1 & 2 & 5.1 & 2.28 & Distinctly Part \\
\hline $\begin{array}{l}\text { Change in responsibilities at } \\
\text { work }\end{array}$ & 2 & 5.1 & 10 & 25.6 & 22 & 56.4 & 5 & 12.8 & 2.23 & Distinctly Part \\
\hline $\begin{array}{l}\text { Heavy demands on classroom } \\
\text { structuring }\end{array}$ & 1 & 2.6 & 10 & 25.6 & 23 & 59 & 5 & 12.8 & 2.18 & Distinctly Part \\
\hline $\begin{array}{l}\text { Handling subjects that are not } \\
\text { in line with specialization }\end{array}$ & 0 & 0 & 10 & 25.6 & 22 & 56.4 & 7 & 17.9 & 2.08 & Distinctly Part \\
\hline $\begin{array}{l}\text { Not receiving the salary on } \\
\text { time }\end{array}$ & 3 & 7.7 & 8 & 20.5 & 16 & 41 & 12 & 30.8 & 2.05 & Distinctly Part \\
\hline $\begin{array}{l}\text { Unexpected } \\
\text { assignment/designation }\end{array}$ & 1 & 2.6 & 6 & 15.4 & 18 & 46.2 & 14 & 35.9 & 1.85 & Distinctly Part \\
\hline Conflict with co-teachers & 1 & 2.6 & 2 & 5.1 & 24 & 61.5 & 12 & 30.8 & 1.79 & Distinctly Part \\
\hline Disliking fellow teacher(s) & 2 & 5.1 & 1 & 2.6 & 15 & 38.5 & 21 & 53.8 & 1.59 & Distinctly Part \\
\hline Conflict with principal/superior & 0 & 0 & 3 & 7.9 & 11 & 28.9 & 24 & 63.2 & 1.45 & $\begin{array}{c}\text { Only } \\
\text { slightly part }\end{array}$ \\
\hline All Sources of Stress & & & & & & & & & 2.43 & Distinctly Part \\
\hline
\end{tabular}

Legend:

$0.00-0.49=$ Not at all part of my life

$0.50-1.49=$ Only slightly part of my life

$1.50-2.49=$ Distinctly part of my life

$2.50-3.00=$ Very much part of my life 
Results revealed that of the twenty-four work-related sources of stress identified, eleven (11) sources of stress were considered very much part of the respondents' lives and these included: Dissatisfaction with the distribution and retrieval of students' modules (3.49) Heavy demands for printing and sorting of students' modules (3.08) ), A lot of examinations/ students' modules or paper works to check (3.08), Dissatisfaction with the attitudes of the students towards answering the modules (2.92), Shortage of school supplies for the printing of students' modules (2.82), Preparing and editing students' modules (2.64) lot of work responsibilities (2.77), Dissatisfaction with the learning styles/abilities of the students (2.59), Preparing rushed documents (2.54), Meeting deadlines (2.54), Preparing for the school evaluation/school visitation (2.50).

This shows that teaching entails a lot of responsibilities as those mentioned above. And these are very much part of the respondents' work.

On the other hand, twelve (12) work-related sources of stress were rated by the respondents to be distinctly part of their lives. These were the following: Preparing Work Weekly plan (2.49), preparing instructional materials(2.46), rendering service beyond the official time (2.44), Dissatisfaction with the teaching materials provided by the school (2.41), heavy demands from the supervisor(2.28), change in responsibilities at work (2.23), heavy demands on classroom structuring (2.18), handling subjects that are not in line with specialization (2.08), not receiving the salary on time(2.05), unexpected assignment/designation (1.85), conflict with co-teachers 1.79 , disliking fellow teacher(s)( 1.59$)$.

Only one (1) work-related source of stress which is a conflict with principal/superior (1.45) was considered only slightly part of the respondents' lives which means that the respondents seldom encounter this and which also implies that teachers have a good working relationship with their superiors.

The overall mean rating of 2.43 described as "Distinctly part of my life" indicates that the respondents generally perceive these work-related sources of stress to have caused them stress. This shows that respondents had some irritations when it comes to teaching-related tasks during this time of the pandemic. These sources of stress are common among teachers as these are roles expected of them to perform.

Results confirmed what iProject (2021) stated that teaching is not only hard work; it can be full of stress. The results also conformed to his statement that poor working conditions, the burden of paperwork, and lack of resources have all been identified as factors that can cause teacher stress.

4.4 Family-related Sources of Stress as Perceived by the Respondents

Table 4. Family-related sources of stress as perceived by the respondents.

\begin{tabular}{|c|c|c|c|c|c|c|c|c|c|c|}
\hline \multirow[t]{2}{*}{$\begin{array}{c}\text { Family-related Sources of } \\
\text { Stress }\end{array}$} & \multicolumn{2}{|c|}{$\begin{array}{c}\text { Very much } \\
\text { part of my life }\end{array}$} & \multicolumn{2}{|c|}{$\begin{array}{l}\text { Distinctly part } \\
\text { of my life }\end{array}$} & \multicolumn{2}{|c|}{$\begin{array}{c}\text { Only } \\
\text { slightly part of } \\
\text { my life }\end{array}$} & \multicolumn{2}{|c|}{$\begin{array}{c}\text { Not at } \\
\text { all part of my } \\
\text { life }\end{array}$} & \multirow[t]{2}{*}{$\begin{array}{l}\text { Mean } \\
\text { Score }\end{array}$} & \multirow[t]{2}{*}{ Description } \\
\hline & $f$ & $\%$ & $f$ & $\%$ & $f$ & $\%$ & $f$ & $\%$ & & \\
\hline $\begin{array}{l}\text { Making important decisions } \\
\text { about the family }\end{array}$ & 9 & 23.7 & 12 & 31.6 & 11 & 28.9 & 6 & 15.8 & 2.69 & Very much part \\
\hline Housekeeping standards & 8 & 20.5 & 6 & 15.4 & 19 & 48.7 & 6 & 15.4 & 2.41 & Distinctly Part \\
\hline $\begin{array}{l}\text { Financial conflicts within the } \\
\text { family }\end{array}$ & 4 & 10.3 & 7 & 17.9 & 19 & 48.7 & 9 & 23.1 & 2.15 & Distinctly Part \\
\hline $\begin{array}{l}\text { The behavior of a family } \\
\text { member }\end{array}$ & 3 & 7.7 & 7 & 17.9 & 15 & 38.5 & 14 & 35.9 & 1.97 & Distinctly Part \\
\hline Spousal relationship & 5 & 12.8 & 3 & 7.7 & 11 & 28.2 & 20 & 51.3 & 1.82 & Distinctly Part \\
\hline $\begin{array}{l}\text { A distance of work station } \\
\text { from the family }\end{array}$ & 4 & 10.3 & 6 & 15.4 & 7 & 17.9 & 22 & 56.4 & 1.79 & Distinctly Part \\
\hline Conflict with spouse & 2 & 5.1 & 3 & 7.7 & 15 & 38.5 & 19 & 48.7 & 1.69 & Distinctly Part \\
\hline Insufficient couple time & 2 & 5.1 & 3 & 7.7 & 15 & 38.5 & 19 & 48.7 & 1.69 & Distinctly Part \\
\hline Conflict with spouse's family & 2 & 5.1 & 4 & 10.3 & 10 & 25.6 & 23 & 59 & 1.62 & Distinctly Part \\
\hline $\begin{array}{l}\text { Family member/s were } \\
\text { infected with COVID -19 }\end{array}$ & 3 & 7.7 & 1 & 2.6 & 3 & 7.7 & 32 & 82.1 & 1.36 & $\begin{array}{c}\text { Only } \\
\text { Slightly Part }\end{array}$ \\
\hline All Sources of Stress & & & & & & & & & 1.92 & Distinctly Part \\
\hline
\end{tabular}

Legend:

$0.00-0.49=$ Not at all part of my life

$0.50-1.49=$ Only slightly part of my life 


$$
\begin{aligned}
& 1.50-2.49=\text { Distinctly part of my life } \\
& 2.50-3.00=\text { Very much part of my life }
\end{aligned}
$$

Data revealed that among the ten (10) family-related sources of stress enumerated, one source was considered "very much part of the respondents" lives, and this was "making important decisions about the family" (2.69).

This is so because most of the respondents are married so they often find themselves in situations where they have to make important decisions concerning their families. Besides, married female teachers are expected to live up to certain housekeeping standards and decisions.

The other family-related sources of stress, namely: financial conflicts within the family (2.15); behavior of a family member (1.97); a distance of work station from the family (1.79); spousal relationship (1.82); insufficient couple time (1.69); Housekeeping standards (2.41), conflict with spouse (1.69); and conflict with spouse's family (1.62) were noted as Distinctly part of the respondents' lives.

There is only one family-related source of stress that was considered "only slightly part of respondents life, and this was "Family member/s were infected with COVID -19" (1.36). This result means the respondents' family members were not be infected by covid 19.

The overall perceived family-related sources of stress had a mean rating of 1.92: described as "Distinctly part of the respondents' lives". It implies that the respondents experienced somewhat stress when it comes to family-related matters.

\subsection{Personal-related Sources of Stress as Perceived by the Respondents}

\begin{tabular}{|c|c|c|c|c|c|c|c|c|c|c|}
\hline \multirow[t]{2}{*}{$\begin{array}{c}\text { Personal - related Sources } \\
\text { of Stress }\end{array}$} & \multicolumn{2}{|c|}{$\begin{array}{l}\text { Very much } \\
\text { part of my life }\end{array}$} & \multicolumn{2}{|c|}{$\begin{array}{l}\text { Distinctly part } \\
\text { of my life }\end{array}$} & \multicolumn{2}{|c|}{$\begin{array}{c}\text { Only } \\
\text { slightly part of } \\
\text { my life }\end{array}$} & \multicolumn{2}{|c|}{$\begin{array}{c}\text { Not at } \\
\text { all part of my } \\
\text { life }\end{array}$} & \multirow[t]{2}{*}{$\begin{array}{l}\text { Mean } \\
\text { Score }\end{array}$} & \multirow[t]{2}{*}{ Description } \\
\hline & $f$ & $\%$ & $f$ & $\%$ & $f$ & $\%$ & $f$ & $\%$ & & \\
\hline $\begin{array}{l}\text { Afraid of being infected by } \\
\text { COVID-19 }\end{array}$ & 13 & 33.3 & 13 & 33.3 & 9 & 23.1 & 4 & 10.3 & 2.9 & Very much part \\
\hline Financial burdens & 7 & 17.9 & 14 & 35.9 & 13 & 33.3 & 5 & 12.8 & 2.59 & Very much part \\
\hline Not enough leisure time & 5 & 12.8 & 12 & 30.8 & 16 & 41 & 6 & 15.4 & 2.41 & Distinctly Part \\
\hline $\begin{array}{l}\text { Important decisions about a } \\
\text { future career for } \\
\text { upgrading teaching } \\
\text { competence }\end{array}$ & 3 & 7.7 & 13 & 33.3 & 20 & 51.3 & 3 & 7.7 & 2.41 & Distinctly Part \\
\hline Time management worries & 5 & 12.8 & 7 & 17.9 & 25 & 64.1 & 2 & 5.1 & 2.38 & Distinctly Part \\
\hline $\begin{array}{l}\text { Too many things to do at } \\
\text { once }\end{array}$ & 5 & 12.8 & 9 & 23.1 & 20 & 51.3 & 5 & 12.8 & 2.36 & Distinctly Part \\
\hline Not enough time to sleep & 4 & 10.3 & 10 & 25.6 & 20 & 51.3 & 5 & 12.8 & 2.33 & Distinctly Part \\
\hline $\begin{array}{l}\text { Poor health including } \\
\text { allergies }\end{array}$ & 3 & 7.7 & 5 & 12.8 & 19 & 48.7 & 12 & 30.8 & 1.97 & Distinctly Part \\
\hline All Sources of Stress & & & & & & & & & 2.42 & Distinctly Part \\
\hline
\end{tabular}

Table 5. Personal-related sources of stress as perceived by the respondents.

Legend:

$$
\begin{aligned}
& 0.00-0.49=\text { Not at all part of my life } \\
& 0.50-1.49=\text { Only slightly part of my life } \\
& 1.50-2.49=\text { Distinctly part of my life } \\
& 2.50-3.00=\text { Very much part of my life }
\end{aligned}
$$

Of the eight (8) personal-related sources of stress identified, two (2) sources namely: financial burdens (2.59); Afraid of being infected by COVID-19 (2.90), were noted as very much part of the respondents' lives. This implies that the teachers often experience financial difficulties that affect their decisions regarding professional upliftment.

The respondents considered six (6) sources as distinctly part of their lives and these were: not enough leisure time (2.41); time management worries (2.38); not enough time to sleep (2.33); poor health including allergies (1.97). Important decisions about future career for upgrading teaching competence (2.41); and too many things to do at once (2.36). 
This result implies that respondents are also often saddled with work as teachers, spouses, and parents. It conforms to the statement of DeLongis et al. as cited by Morgan (1986) that finances and work are some of the important stressors.

The mean score of 2.42 described as "distinctly part" of the respondents' lives indicates the contribution of these personalrelated sources of stress to the respondents' perceived stress.

This implies that the teachers should learn how to manage the time that will able them to balance their work and personal lives.

Atkinson et al. (1996) stated that countless events create stress. Everyday hassles can also be experienced as stressors. Finally, the source of stress can be within the individual in the form of conflicting motives or desires.

\subsection{Environment-related Sources of Stress as Perceived by the Respondents}

Table 6. Environment-related sources of stress as perceived by the respondents.

\begin{tabular}{|c|c|c|c|c|c|c|c|c|c|c|}
\hline \multirow[t]{2}{*}{$\begin{array}{c}\text { Environment-related Sources } \\
\text { of Stress }\end{array}$} & \multicolumn{2}{|c|}{$\begin{array}{c}\text { Very much } \\
\text { part of my life }\end{array}$} & \multicolumn{2}{|c|}{$\begin{array}{l}\text { Distinctly part } \\
\text { of my life }\end{array}$} & \multicolumn{2}{|c|}{$\begin{array}{c}\text { Only } \\
\text { slightly part of } \\
\text { my life }\end{array}$} & \multicolumn{2}{|c|}{$\begin{array}{c}\text { Not at } \\
\text { all part of my } \\
\text { life }\end{array}$} & \multirow[t]{2}{*}{$\begin{array}{l}\text { Mean } \\
\text { Score }\end{array}$} & \multirow[t]{2}{*}{ Description } \\
\hline & $f$ & $\%$ & $f$ & $\%$ & $f$ & $\%$ & $f$ & $\%$ & & \\
\hline $\begin{array}{l}\text { Difficulties with } \\
\text { transportation due to } \\
\text { social distancing and } \\
\text { lockdown in some places } \\
\text { to go. }\end{array}$ & 6 & 15.4 & 8 & 20.5 & 11 & 28.2 & 14 & 35.9 & 2.15 & Distinctly Part \\
\hline Weather conditions & 3 & 7.7 & 5 & 12.8 & 21 & 53.8 & 10 & 25.6 & 2.03 & Distinctly Part \\
\hline Neighbors & 4 & 10.3 & 2 & 5.1 & 19 & 48.7 & 14 & 35.9 & 1.9 & Distinctly Part \\
\hline All Sources of Stress & & & & & & & & & 2.03 & Distinctly Part \\
\hline
\end{tabular}

Legend:

$$
\begin{aligned}
& 0.00-0.49=\text { Not at all part of my life } \\
& 0.50-1.49=\text { Only slightly part of my life } \\
& 1.50-2.49=\text { Distinctly part of my life } \\
& 2.50-3.00=\text { Very much part of my life }
\end{aligned}
$$

The respondents considered the three (3) enumerated environment-related sources of stress to be distinctly part of their lives and these were: difficulties with transportation due to social distancing and lockdown in some places to go (2.15), weather conditions (2.03), and neighbors (1.92).

The obtained mean score of 2.03 for environment-related sources of stress described as "distinctly part" implies that the respondents' sources of stress were perceived to have contributed to their level of stress. This result further implies that respondents were not that comfortable with their environment since they experience somewhat stress when it comes to it.

Generally, the four sources of stress namely work, family, personal, and environment were perceived by the respondents to have contributed stress to them.

DeLongis et al., as cited by Morgan (1986), said that the hassles of everyday life centering around work, family, social activities,

\begin{tabular}{|c|c|c|c|c|}
\hline Activity & $\begin{array}{l}\text { Frequency ( } \mathrm{n} \\
=39)\end{array}$ & Percent & $\begin{array}{l}\text { Mean } \\
\text { Rating }\end{array}$ & Descriptive Rating \\
\hline \multicolumn{5}{|l|}{ 1. Exercise } \\
\hline Walking & 39 & 100 & 3.69 & Very Often \\
\hline Stretching & 39 & 100 & 3.08 & Fairly Often \\
\hline Running & 39 & 100 & 2.31 & Sometimes \\
\hline Jogging & 39 & 100 & 2.15 & Sometimes \\
\hline Swimming & 39 & 100 & 2.10 & Sometimes \\
\hline Weight lifting & 38 & 97.4 & 1.61 & Sometimes \\
\hline Bicycling & 39 & 100 & 1.56 & Sometimes \\
\hline
\end{tabular}
health, and finances are important stressors that are related to bodily illness.

\subsection{Activities Engaged in by the Respondents to Manage Stress}

Table 7. Activities engaged in by the respondents to manage stress. 


\begin{tabular}{|c|c|c|c|c|}
\hline Skating & 39 & 100 & 1.10 & Almost Never \\
\hline Rollerblading & 39 & 100 & 1.10 & Almost Never \\
\hline \multicolumn{5}{|l|}{ 2. Engaging in sports } \\
\hline Badminton & 38 & 97.4 & 2.31 & Sometimes \\
\hline Table tennis & 39 & 100 & 1.23 & Almost Never \\
\hline Lawn tennis & 39 & 100 & 1.00 & Almost Never \\
\hline Golf & 39 & 100 & 1.00 & Almost Never \\
\hline 3. Meditation & 39 & 100 & 3.31 & Fairly Often \\
\hline \multicolumn{5}{|l|}{ 4. Mental activities } \\
\hline Solving puzzles & 39 & 100 & 2.15 & Sometimes \\
\hline Playing board games & 39 & 100 & 2.13 & Sometimes \\
\hline Playing Rubik's cube & 39 & 100 & 1.59 & Sometimes \\
\hline \multicolumn{5}{|l|}{ 5. Spiritual or Religions Activities } \\
\hline Praying & 39 & 100 & 4.15 & Very Often \\
\hline Attending church/religious service & 39 & 100 & 3.59 & Very Often \\
\hline Singing Christian songs & 39 & 100 & 3.26 & Fairly Often \\
\hline Reading bible & 39 & 100 & 3.08 & Fairly Often \\
\hline Prayer meetings/bible studies with family members & 39 & 100 & 2.46 & Sometimes \\
\hline Going on a mission work & 39 & 100 & 1.56 & Sometimes \\
\hline 6. Talking with family, friends, or other supportive people & 39 & 100 & 4.13 & Very Often \\
\hline \multicolumn{5}{|l|}{ 7. Hobbies or Leisure Activities } \\
\hline Cleaning the surroundings & 39 & 100 & 4.23 & Very Often \\
\hline Planting, gardening, and Watering plants & 39 & 100 & 4.05 & Very Often \\
\hline Cooking/baking & 39 & 100 & 3.59 & Very Often \\
\hline Washing domes & 39 & 100 & 3.56 & Very Often \\
\hline Reading newspapers, magazines, etc & 39 & 100 & 3.10 & Fairly Often \\
\hline \multicolumn{5}{|l|}{ 8. Time Management Activities } \\
\hline Evaluating oneself & 39 & 100 & 3.54 & Very Often \\
\hline Scheduling future activities & 39 & 100 & 3.41 & Fairly Often \\
\hline Planning ahead & 39 & 100 & 3.38 & Fairly Often \\
\hline 9. Drinking alcoholic beverages & 39 & 100 & 2.00 & Sometimes \\
\hline 10. Smoking & 39 & 100 & 1.21 & Almost Never \\
\hline 11. Eating & 39 & 100 & 3.46 & Fairly Often \\
\hline 12. Shopping & 39 & 100 & 2.97 & Fairly Often \\
\hline \multicolumn{5}{|l|}{ 13. Watching television } \\
\hline Watching entertainment programs & 39 & 100 & 4.10 & Very Often \\
\hline Watching news & 39 & 100 & 4.08 & Very Often \\
\hline Watching "teledramas"/ "telenovelas" & 39 & 100 & 3.54 & Very Often \\
\hline 14. Listening to music & 39 & 100 & 4.26 & Very Often \\
\hline 15. Texting & 39 & 100 & 3.64 & Very Often \\
\hline 16. Going to the Internet & 39 & 100 & 3.08 & Very Often \\
\hline \multicolumn{5}{|l|}{ 17. Ballroom Dancing } \\
\hline Waltz & 39 & 100 & 2.23 & Sometimes \\
\hline Cha-cha & 39 & 100 & 1.56 & Sometimes \\
\hline Boogie & 39 & 100 & 1.38 & Almost Never \\
\hline 18. Taking over-the-counter drugs & 39 & 100 & 1.90 & Sometimes \\
\hline 19. Massage & 39 & 100 & 2.97 & Fairly Often \\
\hline 20. Naps/Sleeping & 39 & 100 & 3.10 & Fairly Often \\
\hline \multicolumn{5}{|l|}{ 21. Sex } \\
\hline Sexual intercourse & 39 & 100 & 1.97 & Sometimes \\
\hline Masturbation & 39 & 100 & 1.36 & Almost Never \\
\hline 22. Window shopping/Mailing & 39 & 100 & 2.72 & Fairly Often \\
\hline 22. Scanning/ browsing product catalog & 39 & 100 & 2.23 & Sometimes \\
\hline
\end{tabular}


Legend:

Note: Respondents had multiple responses

$$
\begin{aligned}
& 1.00-1.49=\text { Almost never } \\
& 1.50-2.49=\text { Sometimes } \\
& 2.50-3.49=\text { Fairly often } \\
& 3.50-4.00=\text { Very often }
\end{aligned}
$$

Of the activities considered in this study, fifteen were very often done by the respondents to manage stress and these were Walking, Attending church/religious service, Praying, Planting, gardening, and Watering plants, Washing domes, Cooking/baking, Evaluating oneself, Watching the news, Watching entertainment programs, Watching "teledramas"/ "telenovelas", Listening to music, Texting, Going to the Internet, talking with a family member and praying. This is so because talking with family members and airing to them one's problems can relieve a person of stress. Most often, casual talks with family members can be relaxing.

On the other hand, praying can relieve stress especially if a person learns to lift to God all his worries.

Meanwhile, twelve of the activities considered in the study were found to be fairly often done by the respondents to handle their stress and these were: Stretching, Meditation, Reading the bible, Singing Christian songs, Reading newspapers, magazines, Planning, Scheduling future activities, Eating, Shopping, Massage, Naps/Sleeping, and Window shopping.

Some of the activities were sometimes done by the respondents to relieve them of stress and these were: running, weight lifting, jogging, bicycling, swimming, playing badminton, solving puzzles, playing board games, playing rubric's cube, Prayer meetings/bible studies with family members, Going on mission work, Drinking alcoholic beverages, ballroom dancing (cha-cha and waltz) taking over the counter drugs, and sexual intercourse,

The rest of the activities were almost never done by the respondents and these were Skating, Rollerblading, Lawn tennis, Table

\begin{tabular}{|c|c|c|c|c|c|c|c|c|c|c|c|c|}
\hline \multirow{2}{*}{ Item } & \multicolumn{2}{|c|}{ Very High } & \multicolumn{2}{|c|}{ High } & \multicolumn{2}{|c|}{ Moderate } & \multicolumn{2}{|c|}{ Low } & \multicolumn{2}{|c|}{ Very low } & \multirow{2}{*}{$\begin{array}{l}\text { Mean } \\
\text { Score }\end{array}$} & \multirow{2}{*}{ Description } \\
\hline & $f$ & $\%$ & $f$ & $\%$ & f & $\%$ & $f$ & $\%$ & $f$ & $\%$ & & \\
\hline $\begin{array}{l}\text { Afraid that you or your } \\
\text { family members may infect } \\
\text { by COVID- } 19 \text {. }\end{array}$ & 7 & 17.9 & 8 & 20.5 & 22 & 56.4 & 1 & 2.6 & 1 & 2.6 & 3.49 & High Stress \\
\hline $\begin{array}{l}\text { Been upset because of } \\
\text { something that happened } \\
\text { unexpectedly. }\end{array}$ & 1 & 2.6 & 10 & 25.6 & 26 & 66.7 & 2 & 5.1 & 0 & 0 & 3.26 & High Stress \\
\hline Felt nervous and stressed. & 0 & 0 & 10 & 25.6 & 28 & 71.8 & 1 & 2.6 & 0 & 0 & 3.23 & High Stress \\
\hline $\begin{array}{l}\text { Not been able to control } \\
\text { irritations in your life. }\end{array}$ & 0 & 0 & 11 & 28.2 & 22 & 56.4 & 6 & 15.4 & 0 & 0 & 3.13 & High Stress \\
\hline $\begin{array}{l}\text { Felt that you were unable to } \\
\text { control the important } \\
\text { things in your life. }\end{array}$ & 2 & 5.1 & 5 & 12.8 & 27 & 69.2 & 4 & 10.3 & 1 & 2.6 & 3.08 & High Stress \\
\hline $\begin{array}{l}\text { Been angered because of } \\
\text { things that happened that } \\
\text { were outside of your } \\
\text { control. }\end{array}$ & 1 & 2.6 & 7 & 17.9 & 22 & 56.4 & 7 & 17.9 & 2 & 5.1 & 2.95 & High Stress \\
\hline $\begin{array}{l}\text { Felt that things were not } \\
\text { going your way. }\end{array}$ & 0 & 0 & 4 & 10.3 & 28 & 71.8 & 7 & 17.9 & 0 & 0 & 2.92 & High Stress \\
\hline $\begin{array}{l}\text { Found that you could not } \\
\text { cope with all the things } \\
\text { that you had to do. }\end{array}$ & 0 & 0 & 6 & 15.4 & 25 & 64.1 & 6 & 15.4 & 2 & 5.1 & 2.9 & High Stress \\
\hline $\begin{array}{l}\text { Felt that you were not on } \\
\text { top of things. }\end{array}$ & 1 & 2.6 & 5 & 12.8 & 21 & 53.8 & 10 & 25.6 & 2 & 5.1 & 2.82 & High Stress \\
\hline $\begin{array}{l}\text { Felt not confident about } \\
\text { your ability to handle your }\end{array}$ & 0 & 0 & 2 & 5.1 & 28 & 71.8 & 7 & 17.9 & 2 & 5.1 & 2.77 & High Stress \\
\hline
\end{tabular}
tennis, Golf, Smoking, Boogie, Masturbation.

\subsection{Level of Perceived Stress of the Respondents}

Table 8. Level of perceived stress of the respondents 


\begin{tabular}{l|l|l|l|l|l|l|l|l|l|l|l|l}
\hline \hline problem. & & & & & & & & & & & & \\
\hline All Items & & & & & & & & & & & 3.05 & High stress \\
\hline \hline
\end{tabular}

\begin{tabular}{ll}
\hline \hline Legend: & $0.00-0.49=$ Very Low Stress \\
& $0.50-1.49=$ Low Stress \\
& $1.50-2.49=$ Moderate Stress \\
$2.50-3.49=$ High Stress \\
$3.50-4.00=$ Very High Stress
\end{tabular}

It can be noted that the respondents rated the following as giving them "high stress": "nervous and afraid that they may be affected by COVID- 19 disease (3.49), "something happened unexpectedly that caused them to be upset" (3.26); "they were nervous that makes them stressed" (3.23); "they had irritations in life that were beyond their control" (3.13); "important things in their life were beyond their control" (3.08); "things happened were outside of their control that caused them to be angered" (2.95); "they felt that things were not going their way"( 2.92); "they had a lot of things to do and found that they could not cope with" (2.90); "they felt that they were not on top of things" (2.82) "and and "they doubted their ability to handle their problems" (2.77).

The overall mean score of 3.05 described as "high stress" indicates that the public junior high school teachers of Aborlan are affected by stress. This implies further that the respondents experience a high amount of stress.

\section{Conclusion}

This study entitled "Stress Management Amidst Covid - 19 Pandemic of Public Junior High School Teachers in Selected Secondary Schools of Aborlan" was conducted to 1) find out the level of perceived stress of the respondents; 2) determine the sources of stress as perceived by the respondents; and 3) determine the activities that the respondents engage in to manage stress.

Results showed that most of the respondents were married females. They had been in the service for a mean of 11.3 years, and almost three-fourths (74.4\%) were Secondary School Teacher I. Their mean teaching load was 26.4 hours per week and had a mean of 27 students per class.

The perceived sources of stress such as work, family, personal, and environment were considered distinctly part of the respondents' lives.

The junior high school teachers in selected secondary schools of Aborlan experience a high level of stress when it comes to work, personal, and environment-related issues.

Of the activities considered in this study, fifteen were very often done by the respondents to manage stress and these were Walking, Attending church/religious service, Praying, Planting, gardening, and Watering plants, Washing domes, Cooking/baking, Evaluating oneself, Watching the news, Watching entertainment programs, Watching "teledramas"/ "telenovelas", Listening to music, Texting, Going to the Internet, talking with a family member and praying. Meanwhile, twelve of the activities considered in the study were found to be fairly often done by the respondents to handle their stress and these were: Stretching, Meditation, Reading the bible, Singing Christian songs, Reading newspapers, magazines, Planning, Scheduling future activities, Eating, Shopping, Massage, Naps/Sleeping, and Window shopping.

Based on the results of the study, the following recommendations were made: The secondary teachers can engage in activities such as Walking, Praying, Attending church/religious service, Planting, gardening, and Watering plants, Washing domes, Cooking/baking, Evaluating oneself, Watching the news, Watching entertainment programs, Watching "teledramas", "telenovelas", Listening to music, Texting, Going to the Internet, and talking with a family member to cope with their stress; The school administrators should come up with a program of activities to lessen the stress of teachers; For a future researcher, similar studies are conducted among public secondary teachers in other districts. A similar study can be conducted on the public elementary teachers in Palawan.

Funding : This research received no external funding.

Conflicts of Interest : The authors declare no conflict of interest in working on this research.

Acknowledgments: With all sincerity, the author wishes to convey and express her gratitude to several people who gave their immeasurable help and effort in the pursuit of this study. 
Dr. Arnaldo G. Ventura, Assistant Schools Division Superintendent, Officer in Charge, Office of the Schools Division for allowing her to conduct the study.

Sir Thong Basaya, for the assistance and encouragement.

Madam Fe D. Agbon, Public Schools District Supervisor of Aborlan North district, for the companionship and laughter she shared with the author;

Her friend, Madam Neth P. Anunciado, for her valuable assistance in the data analysis;

To Madam Vines, Magbabadil NHS teacher, Marcelo Bantug NHS teachers, and Cabigaan NHS teacher for their cooperation in answering the survey questionnaire.

To her parents, Mr. Leonides Aniete and Mrs. Tessie Aniete, for their prayers, sacrifices, and encouragement;

Her beloved husband, Engr. Romel B. Panis and her children, Lira and Ely for the love, prayers, encouragement, the joy of life, moral support, understanding, and for patiently encoding this manuscript;

Above all, to the Almighty God for the guidance, love, wisdom, and enlightenment that He had bestowed to the author.

\section{References}

[1] American Psychological Association. (2019, 10 18). American Psychological Association. Retrieved from Managing Stress for a Healthy Family: https://www.apa.org/topics/stress/managing-healthy-family

[2] Arora, C. S. (2011, 12 2). Science in Our World: Certainty \& Controversy. Retrieved from Music and Mind: http://www.personal.psu.edu/afr3/blogs/SIOW/2011/12/music-and-mind.html

[3] Clifford T. Morgan, R. A. (1986). Introduction to Psychology. Mc Graw-Hill Brok Companies Inc.

[4] Feldren, R. S. (2005). Understanding Psychology, 7th edition. Mc Graw-Hill.

[5] Gamoso, M. J. (2008). Stress management of faculty members of Western Philippines University. Graduate School, Western Philippines University.

[6] Group, D. E. (2018, July 18). Global Healing Center. Retrieved from Environmental Stress: How It Affects Your Health: https://www.globalhealingcenter.com/natural-health/what-is-environmental-stress/

[7] HAMMY. (2021, 4 12). Stress Relief. Top 10 Stress relievers | HAMMY. Retrieved from My Network. My Nice.: https://curthamiltonnetwork.wordpress.com/2012/09/18/stress-relief-top-10-stress-relievers/

[8] HOSBEG. (2020). HOSBEG. Retrieved from 5 Causes of Stress In The Workplace: https://hosbeg.com/5-causes-stress-workplace/

[9] InterFocus. (2019). Interfocus: Building Laboratory Solutions. Retrieved from Handling Stress in a Laboratory Environment: https://www.mynewlab.com/blog/handling-stress-in-a-laboratory-environment/

[10] iProject. (2021, 4 12). Teachers' Stress and Frustration on the Academic Performance of JSS Students. Retrieved from https://iproject.com.ng/education/teachers-stress-and-frustration-on-the-academic-performance-of-jss-students/index.html

[11] JaniceHealth. (2008). Retrieved from http://www.janicehealth.com/stress.htm

[12] LifePoshive. (2008). Retrieved from http://www.lifeposhive.com/mind/psychology/stress/depressionaspect

[13] NIOSH. (2008). Retrieved from www.cdc.gov/niosh/pdfs/stress.pdf

[14] Ohio State University Extension. (2020). Ohioline. Retrieved from Stress Management: https://ohioline.osu.edu/factsheet/aex-591106

[15] OSHA. (2008). Retrieved from www.osha.gov/Publications/osha3154.pdf

[16] Pera, G. (2021, 4 12). The Tragic Truth Of Prescription Adderall, or "Madderall". Retrieved from ADHD Roller Coaster: https://adhdrollercoaster.org/adhd-news-and-research/the-tragic-truth-of-prescription-adderal-or-madderall/

[17] Rita L. Atkinson, R. C.-H. (1996). Hilgard's Introduction to Psychology. Harcourth Brace \& Company.

[18] Santiago, Cecilia S. 2005. Teaching Commitment of the Faculty Members of the Western Philippines University. Unpublished Masteral Thesis, Western Philippines University, Aborlan, Palawan

[19] Scott, E. (2007). Retrieved from http://stress.about.com/od/generaltechniques/tp/toptensionacts.htm

[20] Scott, E. (2020, 10 22). verywellmind. Retrieved from How Women Can Relieve Their Stress: https://www.verywellmind.com/stress-in-women-3144963

[21] Scott, E. (2020, 6 30). The Benefits of Meditation for Stress Management. Retrieved from An Overview of Meditation: https://www.verywellmind.com/meditation-4157199

[22] Star, K. (2019, 8 10). verywellmind. Retrieved from How Physical Exercise Benefits Mental Health: https://www.verywellmind.com/physicalexercise-for-panic-disorder-and-anxiety-2584094

[23] U.S. National Library of Medicine. (2020, 16 ). MedlinePLus: Trusted Health Information for You. Retrieved from Learn to manage stress: https://medlineplus.gov/ency/article/001942.htm

[24] UCSB Science Line. (2021, 4 12). Retrieved from Encouraging Curiosity for a Lifetime: http://scienceline.ucsb.edu/getkey.php?key=279

[25] UCSB Science Line. (2021, 4 13). UCSB Science Line. Retrieved from Encouraging Curiosity for a Lifetime: http://scienceline.ucsb.edu/getkey.php?key $=279$

[26] Vilibrium. (2021, 4 12). Vilibrium. Retrieved from Top 10 Stress Relievers You Should Try : https://vilibrium.com/stress-de-stress/top-10stress-relievers-you-should-try/

[27] WebMD. (2019). WebMD. Retrieved from Causes of Stress: https://www.webmd.com/balance/guide/causes-of-stress

[28] WikiDoc. (2021, 4 12). Stress Management - WikiDoc. Retrieved from Stress Management: https://wikidoc.org/index.php/Stress_management

[29] Wikipedia, the free encyclopedia. (2020, 1 10). WIKIPEDIA. Retrieved from Stress management: https://en.wikipedia.org/wiki/Stress_management 